\title{
The Fate and Transport of Nutrient and Algal Contaminants in Xiangxi Bay of the Three Gorges Reservoir
}

\author{
Liqiang Yao ${ }^{1}$, Lubo Liu ${ }^{1, *}$, Qingqing Su${ }^{2}$, Yachen Zhang ${ }^{1}$, Congfeng Wang ${ }^{2}$ \\ ${ }^{1}$ Department of Civil and Geomatics Engineering, California State University, Fresno, USA \\ ${ }^{2}$ China Three Gorges University, China
}

Received October 14, 2019; Revised December 23, 2019; Accepted December 25, 2019

Copyright $\bigcirc 2019$ by authors, all rights reserved. Authors agree that this article remains permanently open access under the terms of the Creative Commons Attribution License 4.0 International License

\begin{abstract}
Water quality in the Three Gorges Reservoir and all its tributaries is of critical significance for the ecological and economic development of the middle and lower Yangtze River watershed. The construction of the reservoir impoundment has caused higher water surface elevation, slower current velocity, and even backflow in its main tributaries, including the Xiangxi River. More nutrient species related to nitrogen and phosphorous are being conveyed to the water body and retained in the river's bay region much longer than previously, leading to more frequent eutrophic events such as algal blooms, and significantly threatening the downstream water quality. This study focuses on the nutrient species levels, statistically analyzing the available data to determine the effect of backflow and estimate the variation in algal levels, developing mass balances for the water budget and important contaminants, and calculating the ratio of total nitrogen to total phosphorus. Based on the data from the eutrophication processes happened in the Xiangxi River during the period from January to November 2010, total nitrogen is the limiting factor. The amount of water accumulated in the Xiangxi River was $1.108 \times 10^{10} \mathrm{~m}^{3}$, and the water level rose by $5.78 \mathrm{~m}$ from January to November 2010. Most of the phosphorus and ammonia in the river came from non-point source pollution. The results will be used to help verify and calibrate variations in the water flow rate and the associated point source and non-point source pollution. Since the Xiangxi River is a representative tributary of the Three Gorges Reservoir, the research method developed and conclusions drawn will provide a valuable reference for eutrophication investigations of other tributaries.
\end{abstract}

Keywords Algal Bloom, Correlation, Backflow, Mass Balance

\section{Introduction}

For millennia, rivers have sustained life and promoted the reproduction, survival, and ecological stability of terrestrial aquatic organisms. However, the rise of modern society and industrial development has created significant levels of non-point pollution from domestic sewage, farmland drainage, and other harmful substances that directly or indirectly enter our river systems, leading to deteriorating water quality and changes in the biota. [1] Unfortunately, the construction of dams on many of the world's rivers to harness the benefits and natural resources that rivers can provide often exacerbates these problems as they generally have a negative effect on the local water environment.

As one of the world's largest hydropower engineering structures, the Three Gorges Dam is the backbone of the flood control system in the middle and lower reaches of the Yangtze River, the most important river in China. It provides not only flood control and electricity generation, but also a navigable waterway for the main channel of the Yangtze River. Its ship-lift system enables huge ships to navigate to reach as far inland as Chongqing. In 2003, the Three Gorges Reservoir was successfully impounded, [2] after which the water level in the reservoir area continued to increase and the water flow in the tributary rivers slowed, decreasing their self-purification ability and increasing the retention time of pollutants in the tributary bay.

These changes in the water quality have negatively altered the environment of the aquatic community living within the tributary bay, resulting in serious environmental problems due to eutrophication such as algal blooms. [3] As the largest tributary feeding into the Three Gorges Reservoir, the Xiangxi River is suffering from a similar nutrient pollution problem. [4] As a backwater zone, 
Xiangxi Bay was formed due to the deep impoundment. [5] The hydraulic conditions in this region are similar to those in the reservoir but with the bay's own unique characteristics.

Researchers working on the problem of nutrient pollution, especially that due to nitrogen and phosphorus-containing compounds, contend that their main source is the non-point pollution produced by agricultural wastewater. [6,7] Many of the nutrient species present in polluted water are related to nitrogen and phosphorus, including total nitrogen (TN), nitrate $\left(\mathrm{NO}_{3}{ }^{-}\right)$, ammonium $\left(\mathrm{NH}_{4}{ }^{+}\right)$, total phosphorus (TP), and orthophosphate $\left(\mathrm{PO}_{4}^{-}\right)$. The slower water velocity since the dam was constructed leads to these nutrients staying longer in tributaries such as the Xiangxi River. Under these circumstances, algae propagate in large numbers and eutrophication occurs. Chlorophyll-a is another significant indicator of an algal bloom. Eutrophication usually leads to the creation of dense blooms of noxious phytoplankton that reduce water clarity and harm water quality, [8] and excessive plant growth, such as algae blooms. [9] As these eutrophication processes progress, the aquatic life in the river begins to increasingly die off due to worse water quality. [10]

This research identifies: (1) the spatial-temporal distribution characteristics and concentration variation trends for total nitrogen, nitrate, ammonia, total phosphorus, orthophosphate, chlorophyll-a, and the amount of algae present; (2) the month to month variation in the river's backflow and velocity; (3) the ratio of total nitrogen to total phosphorus; and (4) the mass balance for water and contaminants along the longitudinal direction of the Xiangxi River. As the longest tributary in the Yangtze River, the results obtained for the Xiangxi River are likely to be representative, and thus have guiding significance, for the study of other tributaries feeding into the Three Gorges Dam's reservoir.

\section{Materials and Methods}

\subsection{Site Description}

The Xiangxi River Basin is located on the north side of the Xiling Gorge of the Yangtze River. The Xiangxi Estuary is about $29 \mathrm{~km}$ above the three Gorges Dam, and is the first tributary at the head of the dam's reservoir. The river's current flows from north to south and its watershed range is from $110^{\circ} 25^{\prime}-111^{\circ} 06^{\prime} \mathrm{E}$ to $30^{\circ} 57^{\prime}-31^{\circ} 34^{\prime} \mathrm{N}$, including part of the Shennongjia forest region in Zigui county. The area of the Xiangxi River Basin is $3099 \mathrm{~km}^{2}$, its multi - annual runoff is $47.4 \mathrm{~m}^{3} / \mathrm{s}$, and its average annual rainfall is $1015.6 \mathrm{~mm}$. [4] The Xiangxi River Bay forms after the three Gorges Reservoir reaches its designed water level because the area from the confluence of the Yangtze River and the Xiangxi River to the Baisha River (which is located upstream of the Xiangxi River) are submerged by the backwater area. The study area is shown in Figure 1. A total of 12 sampling sections are located along the river, designated CJXX, XX00, XX01, XX02, XX03, XX04, XX05, XX06, XX07, XX08, XX09, and XX10, in turn, progressing upstream from the mouth of the river. These cross-sections are based on the topography of Xiangxi River Reservoir Bay and the hydrologic situation of the Three Gorges Reservoir. The cross-section is taken to be the middle thread of the Xiangxi River's channel and the interval between each cross-section is 3 kilometers. The range is about 32 kilometers long from the estuary of the Xiangxi River Bay to the reserveoir tail at Zhaojun Township. 


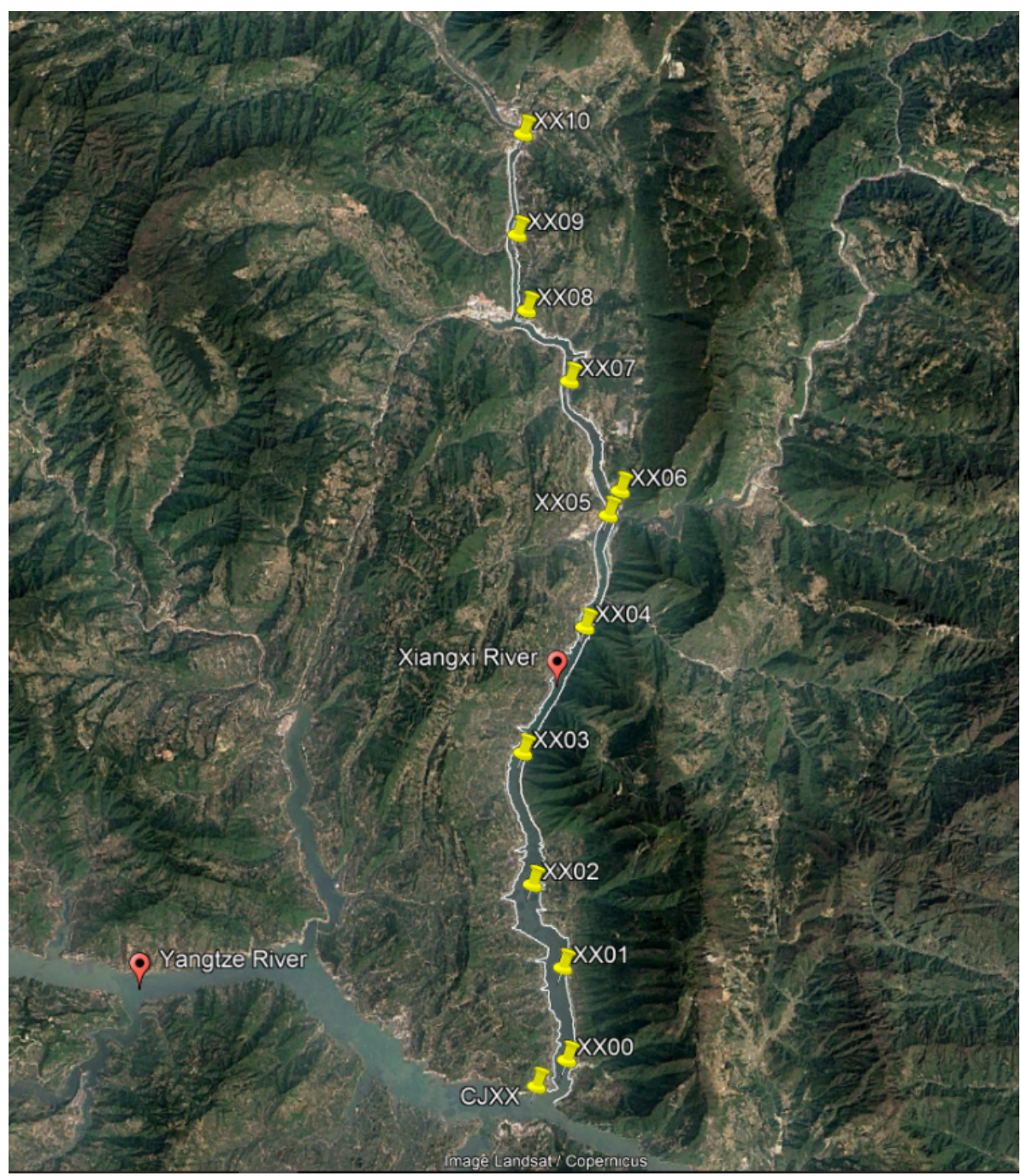

Figure 1. Distribution map of the sample points in the Xiangxi River Bay

The Xiangxi River Basin is located in a high mountain and semi-high mountain area. It has a unique geomorphological characteristics: the east, the west, and the north of the basin have higher ground surface elevations, and the upstream section is steep and has an average altitude of $2,500 \mathrm{~m}$ above sea level. The river flows through a canyon, with a natural drop of up to 1,000 m. [11] The Xiangxi River basin has a subtropical, monsoon, and humid climate. The precipitation in the basin falls mainly from March to October every year, and the wet season starts from April and ends at the end of October. The water and soil loss in the Xiangxi River Basin is quite serious, and Xingshan County where the basin is located, in particular is subject to intense erosion. During the wet season, a large amount of sediment is scoured into the river, leading to the increasing elevation of the riverbed. Each year, 8,700 tons of nitrogen and 4,700 tons of phosphorus are transported into the river as a result of soil loss and water runoff. $[12,13]$

The Three Gorges Reservoir (105 $44^{\prime}-111^{\circ} 39^{\prime}$ E, $28^{\circ} 32^{\prime} \sim 31^{\circ} 44^{\prime} \mathrm{N}$ ), shown in Figure 2, extends from the west of Hubei Province to the central and eastern part of Chongqing, with a total length of about $660 \mathrm{~km}$. The overall topography is high in the west and low in the east. $[4,14]$ The width of the reservoir surface is between $700 \sim 1,700 \mathrm{~m}$ in the mainstream and $300 \sim 600 \mathrm{~m}$ at the mouths of the tributaries. The normal storage level of the three Gorges Reservoir is $175 \mathrm{~m}$.

The water surface elevations in the flood season and dry period are $145 \mathrm{~m}$ and $155 \mathrm{~m}$, respectively.[15] Under the natural conditions, the mainstream velocity in the Yangtze River from Chongqing to Yichang is generally around 2 to $3 \mathrm{~m} / \mathrm{s}$. [14] In this research, river flow and its impact on the fate and transport of the nutrient contaminants and algae in the Xiangxi River are investigated through the data analysis. The flow data and the concentrations of various water quality parameters are analyzed in the following four aspects: 1 . Temporal variation of the parameters, 2 . Cross correlations between different parameters, 3. Ratio of nitrogen to phosphorous, and 4 . Water budget and mass balance of contaminants 


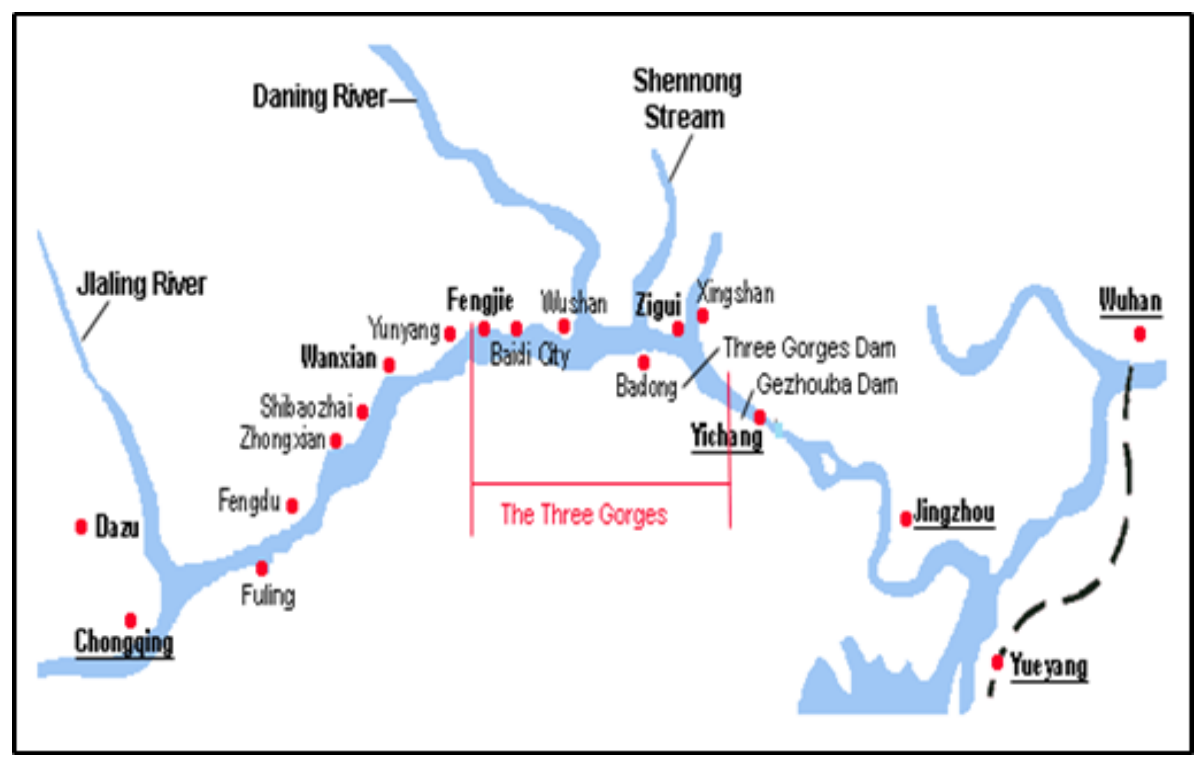

Figure 2. Diagrammatic sketch of the Three Gorges Reservoir

1. Temporal variation of the parameters

Observed data of flow and water quality were collected in 2010 to identify the variation trends and distribution characteristics of different parameters for the upstream, midstream, and downstream of the Xiangxi River. The plots of time serials and spatial distribution were mainly used for the data analysis. In this study, these parameters include flowrate, flow velocity, total nitrogen, nitrate, ammonia, total phosphorus, orthophosphate, chlorophyll-a, and algae.

\section{Cross-correlation between the parameters}

Cross-correlation, or the degree of correlation between two data series, $[16,17]$ is used to investigate variations in the regulation of variables over time and the relationships between pairs of variables. For the current study, cross-correlation coefficients of multiple factors were analyzed using Matlab to identify factors that correlate well with each other, namely those with a correlation coefficient on 0.7 or above. The cross-correlation between backflow percentage and algae identified through this research was particularly interesting.

\section{Ratio of Nitrogen to Phosphorus}

Determining which nutrient is the limiting factor of the eutrophication, such as algae bloom, is crucial for efforts to control eutrophication. Typically, the known nutrient concentrations and the measured phytoplankton productivity in a lake or river can be used to estimate the nutrient constraints governing the particular ecological system. [18] As nitrogen and phosphorus are the essential nutrients for phytoplankton growth, the limiting nutrient can be determined by calculating the ratio of nitrogen to phosphorus present in water samples. Here, a ratio of nitrogen to phosphorus of less than 7.2 signifies that nitrogen is the limiting factor and is thus likely to be controlling eutrophication; if the ratio is greater than 7.2 but less than 15, eutrophication is affected by both nitrogen and phosphorus; and if the ratio is greater than 15 , eutrophication is mainly limited by phosphorus. Units of $\log _{10}$ TN (total nitrogen) and $\log _{10}$ TP (total phosphorus) were used to track the ratio of nitrogen to phosphorus in the upstream, midstream, and downstream reaches of the Xiangxi River in this study.

\section{Mass Balance}

The mass balance used to determine the relationships between point sources and non-point sources was made up of two components, one for water and the other for contaminants. [19] The mass balance for the watershed is also known as the water budget. It is represented by the following equations: [20]

$$
\frac{d V}{d t}=Q_{\text {in }}-Q_{\text {out }}
$$

Where $Q_{\text {in }}$ includes the precipitation, river inflow, and runoff from groundwater, while $Q_{\text {out }}$ includes the transpiration, evaporation, infiltration, and river outflow.

Although the equation for the contaminant is essentially the same as for the water budget, it must also allow for possible chemical or biological reactions between the contaminant and the water, as shown below: [20]

$$
\begin{gathered}
\left(\frac{d M}{d t}\right)_{a c c}=\left(\frac{d M}{d t}\right)_{i n}-\left(\frac{d M}{d t}\right)_{o u t} \pm\left(\frac{d C}{d t}\right)_{r e c} \\
\left(\frac{d C}{d t}\right)_{r e c}=k_{1} C
\end{gathered}
$$

where $\left(\frac{d C}{d t}\right)_{r e c}$ is the reaction rate of the contaminant, and $k_{1}$ represents the first order coefficient. Here, the value of $k_{1}$ was taken from Liu et al.. [4] Equations 1-3 can now be reformulated as:

$$
\frac{d V C}{d t}=C_{\text {in }} Q_{\text {in }}-C_{\text {out }} Q_{\text {out }}-\mathrm{V} k_{1} C
$$


where $C_{\text {out }}$ is the concentration of the contaminant present in the river water, and $C_{\text {out }}$ becomes $C$ for our purposes, representing the variation of contaminant in river. V and $Q$ represent the volume of the river and its flowrate, respectively.

\section{(1) Water budget}

The water budget calculation (Equation. 1) focused on the variation in the water content in the Xiangxi River. The velocities at five spots of each cross-section of the river were used to calculate the average velocity, further to obtain the flowrate.

\section{(2) Mass balance for contaminants}

The specific equation used to calculate the mass balance for the contaminants is shown in Equation 5:

$$
\begin{gathered}
\mathrm{V} \frac{\mathrm{C}_{\mathrm{t}+\Delta t}-\mathrm{C}_{\mathrm{t}}}{\Delta \mathrm{t}}=\mathrm{C}_{\mathrm{in}, \mathrm{t}+\Delta \mathrm{t}} \mathrm{Q}_{\mathrm{in}}-\mathrm{C}_{\mathrm{t}+\Delta \mathrm{t}} \mathrm{Q}_{\text {out }}-\mathrm{kVC}_{\mathrm{t}+\Delta \mathrm{t}} \\
C_{\text {in }, t+\Delta t} Q_{\text {in }}=C Q_{\text {in-point }}+C Q_{\text {in-non point }}
\end{gathered}
$$

The accumulation was calculated based on the difference between the amount in the target month and that for the previous month. For ammonia nitrogen, $\mathrm{k}$ represents the decomposition rate. The chemical reaction rate of nitrogen varies from $0.001 /$ day to $0.95 /$ day. For total phosphorus, there are three different $\mathrm{k}$ values (Table 1).

Table 1. Chemical reaction rate of total phosphorus

\begin{tabular}{|c|c|c|}
\hline Parameter & $\begin{array}{c}\text { Minimum } \\
\text { theoretical value } \\
\text { (/day) }\end{array}$ & $\begin{array}{c}\text { Maximum } \\
\text { theoretical value } \\
\text { (/day) }\end{array}$ \\
\hline $\begin{array}{c}\text { Kinetic coefficient of } \\
\text { photosynthesis }\end{array}$ & 0.01 & 1.2 \\
\hline $\begin{array}{c}\text { Kinetic coefficient of } \\
\text { mineralization }\end{array}$ & 0.001 & 0.12 \\
\hline $\begin{array}{c}\text { Kinetic coefficient in } \\
\text { the sediment }\end{array}$ & 0.00002 & 0.000032 \\
\hline Total & 0.01102 & 1.320032 \\
\hline
\end{tabular}

The mass balance was calculated for two sections of the river separately, with the first being from the upstream to midstream reaches and the second part from the midstream to downstream reaches. This allowed the amount of material coming from the non-point sources, and hence the percentages from both the point and non-point sources, to be calculated from Equations 5 and 6 .

\section{Results and Discussion}

\subsection{Velocity Analysis}

The average velocity of the main stream of the Yangtze River under natural conditions was around $2 \mathrm{~m} / \mathrm{s}$. [22] After the Three Gorges Dam was impounded, the water flow in the Xiangxi River slowed, encouraging the retention of pollutants. The average river velocity is very slow, at about $0.1 \mathrm{~m} / \mathrm{s}$. In such circumstances, the exchange between water bodies weakens, although a slow flow rate is beneficial for the deposition of matter.

\subsection{Backflow Analysis}

Impounding the Three Gorges Reservoir changed the hydrodynamic characteristics of the Xiangxi River substantially, with backflow becoming commonplace. Table 2 shows the direction of flow in each section of the river, with a negative value indicating backflow and a positive value indicating normal flow. Figure 3 shows the flow rate of the Xiangxi River from upstream to downstream for the first 11 months of 2010 , including backflow quantities.

\begin{tabular}{|c|c|c|c|}
\hline Section & XX09 & XX06 & XX00 \\
\hline 1.16 & -1 & -1 & 1 \\
\hline 1.27 & -1 & 1 & 1 \\
\hline 2.7 & -1 & -1 & 1 \\
\hline 2.18 & -1 & -1 & 1 \\
\hline 2.28 & 1 & 1 & 1 \\
\hline 3.7 & 1 & 1 & -1 \\
\hline 3.14 & -1 & 1 & 1 \\
\hline 3.28 & -1 & 1 & 1 \\
\hline 4.4 & -1 & -1 & 1 \\
\hline 4.12 & -1 & -1 & 1 \\
\hline 4.18 & -1 & -1 & -1 \\
\hline 5.2 & -1 & -1 & -1 \\
\hline 5.16 & -1 & 1 & -1 \\
\hline 5.23 & 1 & -1 & -1 \\
\hline 6.9 & 1 & -1 & -1 \\
\hline 6.2 & -1 & -1 & 1 \\
\hline 7.18 & 1 & 1 & 1 \\
\hline 7.26 & -1 & -1 & -1 \\
\hline 8.2 & -1 & -1 & -1 \\
\hline 8.9 & -1 & 1 & 1 \\
\hline 8.16 & -1 & -1 & 1 \\
\hline 8.22 & -1 & -1 & -1 \\
\hline 9.4 & -1 & 1 & -1 \\
\hline 9.14 & -1 & 1 & 1 \\
\hline 9.20 & -1 & 1 & -1 \\
\hline 9.26 & -1 & -1 & 1 \\
\hline 10.4 & -1 & 1 & -1 \\
\hline 10.1 & -1 & -1 & -1 \\
\hline 10.18 & 1 & 1 & 1 \\
\hline 11.5 & -1 & -1 & 1 \\
\hline
\end{tabular}

Table 2. Velocity direction from $1 / 16$ to $11 / 5$ 


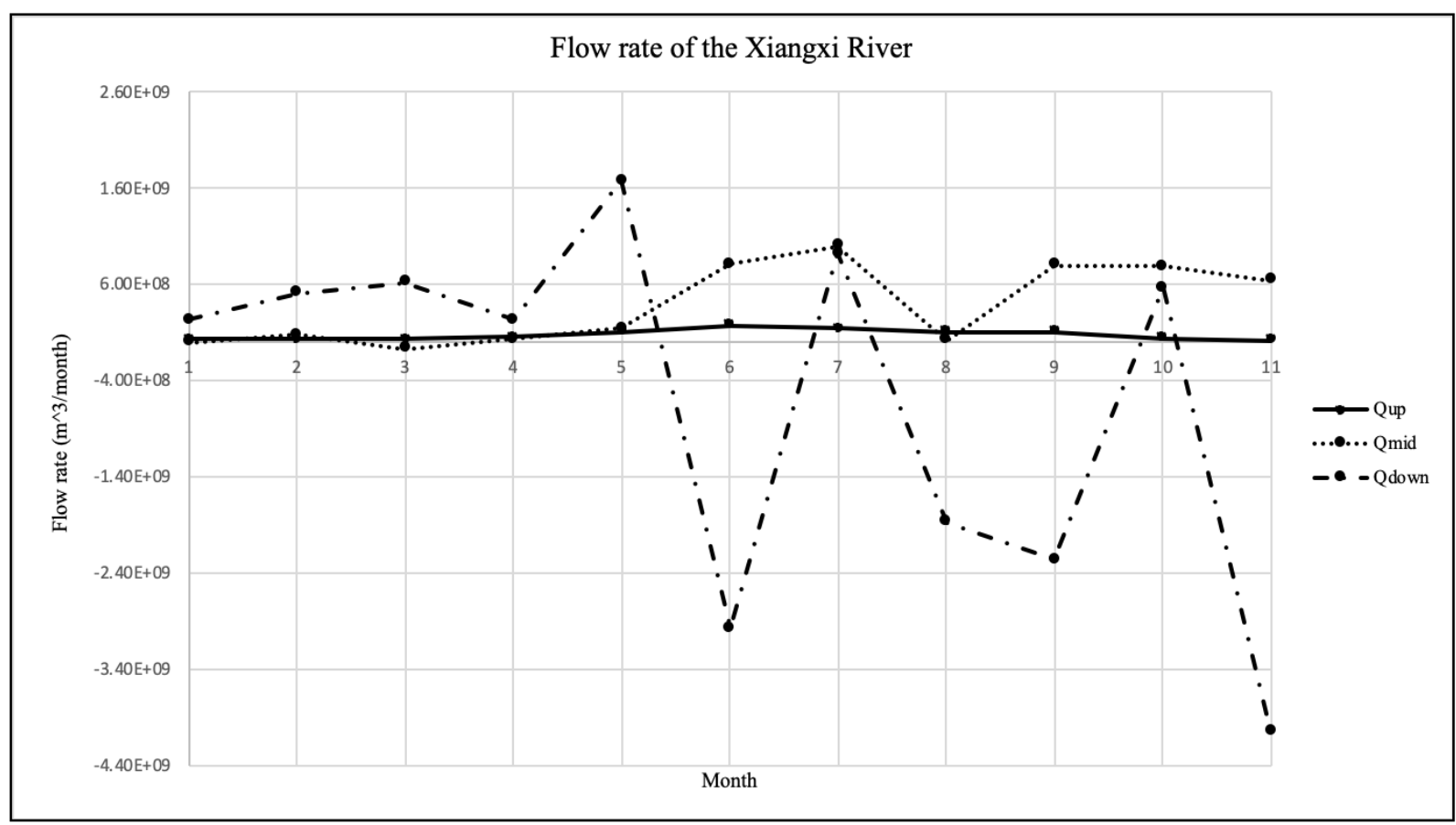

Figure 3. Flow rate of the Xiangxi River (January to November 2010)

As the data presented in these tables show, in many parts of the Xiangxi River backflows occur. Comparing this information with Figure 8, which looks at the variation in the algal density in the upstream, midstream, and downstream reaches of the Xiangxi River, an algal bloom is almost always accompanied by backflow. Although the percentages of backflow events in the upstream, midstream, and downstream reaches are decreasing, Figure 3 suggests that the overall backflow rate from upstream to downstream is increasing, with the backflow rate being especially high in the downstream section close to the reservoir.

The cross-correlation between backflow percentage and algal growth is shown in Figure 4. The backflow percentage represents the percentage of stations in different sections of the stream that are experiencing backflow. Figure 4 shows that the cross-correlation coefficients for the backflow percentage and algal growth in the upstream and midstream reaches of the river are both greater than 0.7 , which indicates there is a good correlation between these two factors. The coefficient is relatively small in the downstream section, however. For the midstream section, the time lag is negative at the highest coefficient, which indicates that the backflow changed after the algae grew, confirming that variations in the amount of algae influence the backflow. In the downstream section, the time lag is 0 at the highest coefficient, which means that the backflow and algae are changing at the same time. In general, variations in the algae influence the hydrodynamic characteristic of the bay area. 


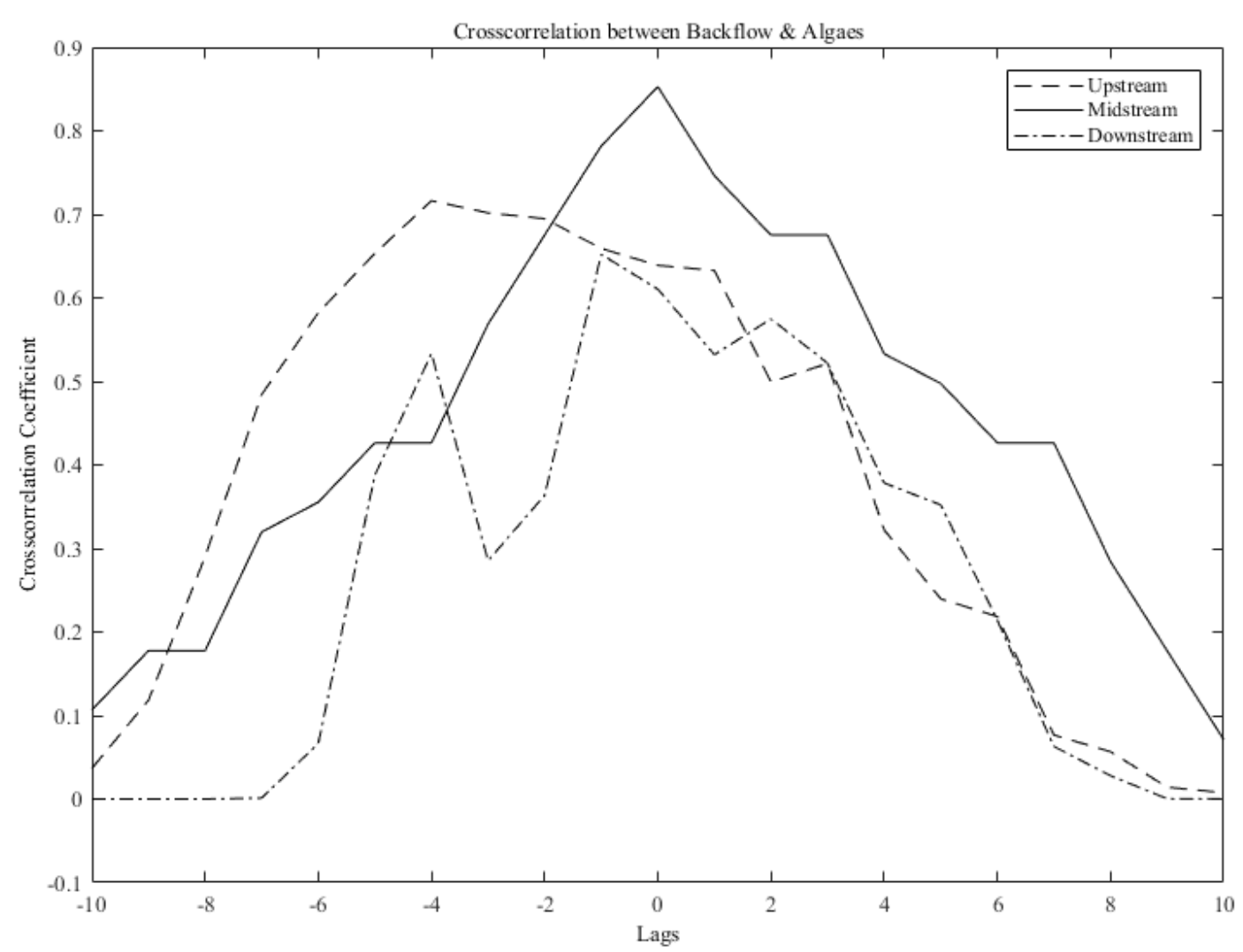

Figure 4. Cross-correlation between the backflow and algal measurements in the upstream, midstream, and downstream reaches of the Xiangxi River

\subsection{Ratio of Total Nitrogen and Total Phosphorus}

The ratio of the total nitrogen to the total phosphorus serves as a useful indicator identifying the limiting factor for the eutrophication. The results shown in Figure 5 show that the ratio of total nitrogen to total phosphorus in the Xiangxi River during the study period was less than 7.2, which indicates that nitrogen is the controlling factor and thus has more influence on the eutrophication process in the Xiangxi River than phosphorus.

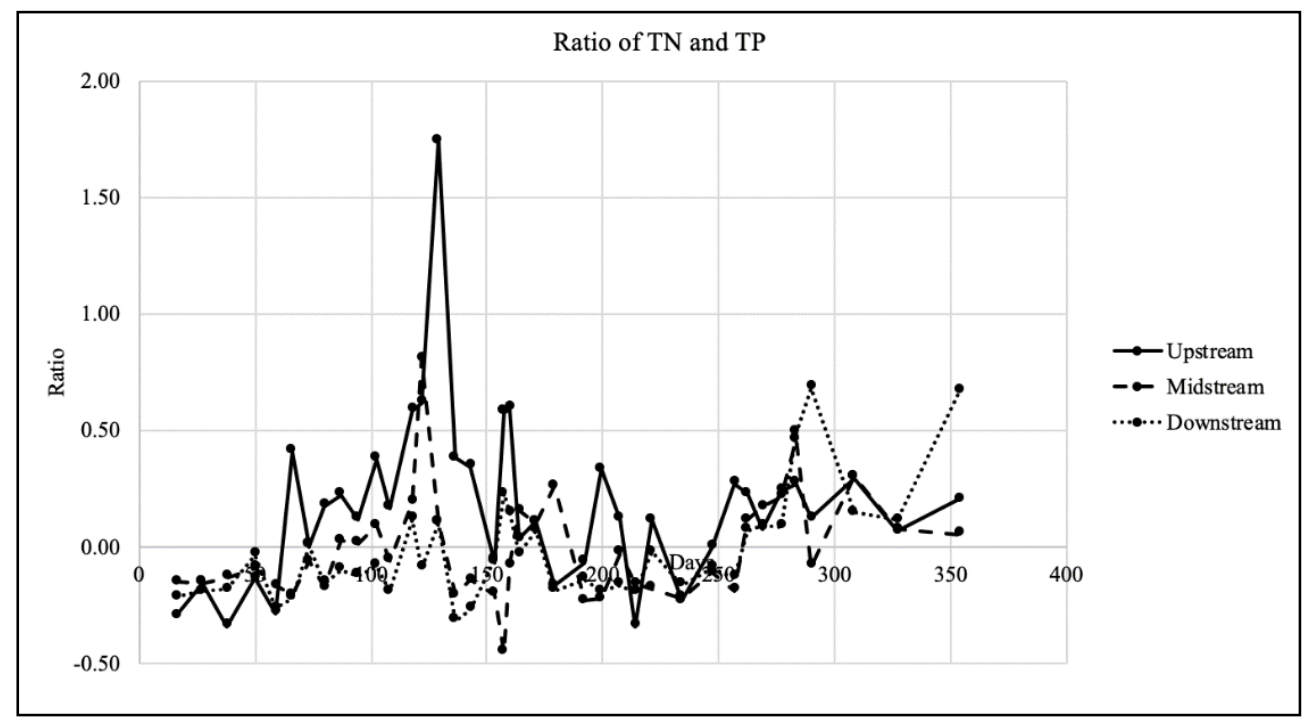

Figure 5. Ratio of nitrogen and phosphorus levels in the Xiangxi River for the study period 


\subsection{Distribution and Variation of Nutrients, Chlorophyll-a, and Algae}

\subsubsection{Total Nitrogen}

Figure 6 shows the variation in the total nitrogen in the upstream, midstream, and downstream reaches of the Xiangxi River. The total nitrogen in the upstream section ranges from $0.07 \mathrm{mg} / \mathrm{L}$ to $2.03 \mathrm{mg} / \mathrm{L}$, from $0.18 \mathrm{mg} / \mathrm{L}$ to $1.76 \mathrm{mg} / \mathrm{L}$ in the midstream section, and from $0.12 \mathrm{mg} / \mathrm{L}$ to $1.85 \mathrm{mg} / \mathrm{L}$ in the downstream section. The average concentrations of total nitrogen are $0.87 \mathrm{mg} / \mathrm{L}, 1.10 \mathrm{mg} / \mathrm{L}$, $1.14 \mathrm{mg} / \mathrm{L}$ in the upstream, midstream, and downstream sections, respectively; all are gradually increasing over time.

The water quality evaluation criteria for lakes and reservoirs are stipulated in the Environmental Quality Standard for Surface Water GB3838-2002, and the recommended limits for nitrogen and phosphorus, as well as other nutrient types, for lakes and reservoirs are specified in the Standard for the Quality of Surface Water Resources SL63-94. Although these standards were originally developed for lakes, they are also suitable for rivers and estuaries. The evaluation criteria for water quality and water resources in lakes and reservoirs are shown in Tables 3 and 4, respectively.

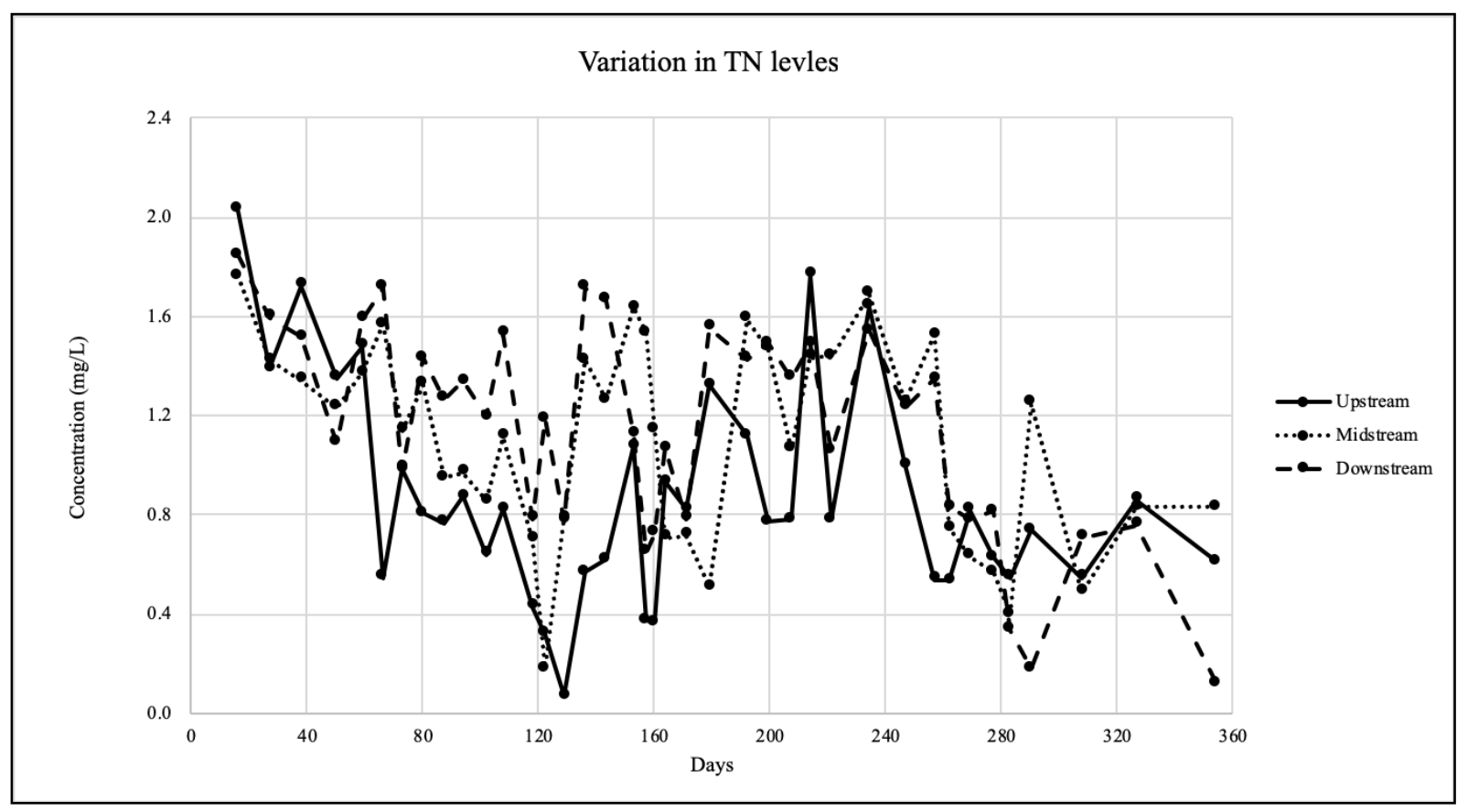

Figure 6. Variation in TN levels in the upstream, midstream, and downstream reaches of the Xiangxi River

Table 3. Evaluation standards for water quality in lakes and reservoirs

\begin{tabular}{|c|c|c|c|c|c|}
\hline $\mathrm{mg} / \mathrm{L}$ & $\mathrm{I}$ & II & III & IV & V \\
\hline $\mathrm{TP}$ & $\leq 0.01$ & $\leq 0.025$ & $\leq 0.05$ & $\leq 0.1$ & $\leq 0.2$ \\
\hline $\mathrm{TN}$ & $\leq 0.2$ & $\leq 0.5$ & $\leq 1.0$ & $\leq 1.5$ & $\leq 2.0$ \\
\hline
\end{tabular}

Table 4. Standard evaluation criteria for water resources

\begin{tabular}{|c|c|c|c|c|}
\hline $\mathrm{mg} / \mathrm{L}$ & $\begin{array}{c}\text { Oligotrophic } \\
\text { (poorly nourished) }\end{array}$ & $\begin{array}{c}\text { Mesotrophic } \\
\text { (moderately nourished) }\end{array}$ & $\begin{array}{c}\text { Eutrophic } \\
\text { (well-nourished) }\end{array}$ & $\begin{array}{c}\text { Hypereutrophic } \\
\text { (over-nourished) }\end{array}$ \\
\hline TP & $\leq 0.02$ & $0.02-0.05$ & $0.05-0.09$ & $>0.09$ \\
\hline $\mathrm{TN}$ & $\leq 0.25$ & $0.25-0.70$ & $0.70-1.30$ & $>1.30$ \\
\hline
\end{tabular}


In these tables, Class I applies to source water and national nature reserves; Class II is for centralized drinking water sources and first class conservation areas such as surface water sources that provide a habitat for rare aquatic organisms, a spawning ground for fish and shrimps, or a feeding grounds for larvae and juveniles; Class III applies mainly to centralized drinking water and second-class conservation areas, including surface water sources such as, fish and shrimp overwintering farms, migration passages, aquaculture areas and other fishing waters and swimming areas; Class IV covers general industrial water areas and non-direct contact with human body entertainment water areas; and Class V applies to agricultural water and that by the landscape in general.

Looking at the average concentration of total nitrogen, the water quality in the Xiangxi River belongs to Classes III and IV. The eutrophication degree is well-nourished, especially from January to February and from June to early September. During these periods, the Xiangxi River exhibits classic over-nourished phenomena, and it is safe to assume that the eutrophication of Xiangxi River is serious.

Figure 6 shows that the concentration fluctuations in the total nitrogen of the upstream section of the study area are relatively large. This is because the total nitrogen concentration in the upper reaches of the Xiangxi River comes mainly from agricultural sources and is thus significantly influenced by rainfall and surface runoff. Under such circumstances, the total nitrogen undergoes major changes in this part of the river. The figure also shows that the concentration of total nitrogen in the downstream part of the river is even higher than that upstream. This is because the total nitrogen concentration in the main channel of the Yangtze River flows backward into the Xiangxi River, significantly affecting the water quality in the Xiangxi River. According to Zhang et al. [21], the total nitrogen and phosphorus flowing from the main stream of the Yangtze River into the Xiangxi River Bay in 2010 made up $43.4 \%$ and $21.5 \%$ of the total, respectively, due to the reverse flow of the main stream.

In an analysis of the nitrogen and phosphorus nutrient levels over the 10 years during which the reservoir impoundment occurred, Ran et al. found that the nitrogen and phosphorus nutrients from the upstream reaches was accounted for by $80 \%$ to $90 \%$ of the water entering the reservoir area. After the Three Gorges Reservoir was impounded, $18 \%$ of total nitrogen and $15 \%$ of total phosphorus was intercepted in the reservoir. [17] This also led to an increase in the total nitrogen in the downstream reaches of the Xiangxi River.

In January, the Xiangxi River is in its dry season, but the concentration of total nitrogen is very high, especially in the upstream eaches. The primary cause of this is that in the dry season the dilution effect of the pollutants in the basin decreases, resulting in a higher concentration of total nitrogen. When the input from non-point sources decreases, the concentration of total nitrogen also decreases. The Xiangxi River enters its wet season from March, but the concentration of total nitrogen is lower and it undergoes a further decrease around May in all three reaches, probably due to the dilution effect of the rainfall. This is also the period when the reservoir drainage increases and water flows faster, thus decreasing the total nitrogen. As the pollutants begin to accumulate again, the total nitrogen concentration begins to increase. The total nitrogen content in the Xiangxi River reaches its peak in the wet season, from June to September.

\subsubsection{Nitrates}

Figure 7 shows the variations in the nitrate levels in the upstream, midstream, and downstream reaches of the Xiangxi River. In the upstream reaches, the nitrate levels range from $0.00 \mathrm{mg} / \mathrm{L}$ to $1.70 \mathrm{mg} / \mathrm{L}$, in the midstream reaches they range from $0.01 \mathrm{mg} / \mathrm{L}$ to $1.63 \mathrm{mg} / \mathrm{L}$, and in the downstream reaches they range from $0.06 \mathrm{mg} / \mathrm{L}$ to 2.51 $\mathrm{mg} / \mathrm{L}$. The average concentrations of nitrates in the river water are $0.46 \mathrm{mg} / \mathrm{L}, 0.70 \mathrm{mg} / \mathrm{L}$, and $0.83 \mathrm{mg} / \mathrm{L}$ in the upstream, midstream, and downstream sections, respectively. Once again, the trends in the concentration variations in all three sections are gradually increasing.

As Figure 7 shows, the variations in the nitrate levels in the upstream, midstream, and downstream reaches are similar to those found for the total nitrogen and the nitrate concentration in the wet season is higher than in the low water season. The flood discharge of the Three Gorges Reservoir creates an inverse flow of the main stream of the Xiangxi River, and the scour of rain water also affects the concentration of nitrate. However, in March the concentration of nitrate is low in the upstream and midstream reaches but high in the downstream section. This is likely due to the inverse flow of the main stream of the Yangtze River washing nitrates into the Xiangxi. 


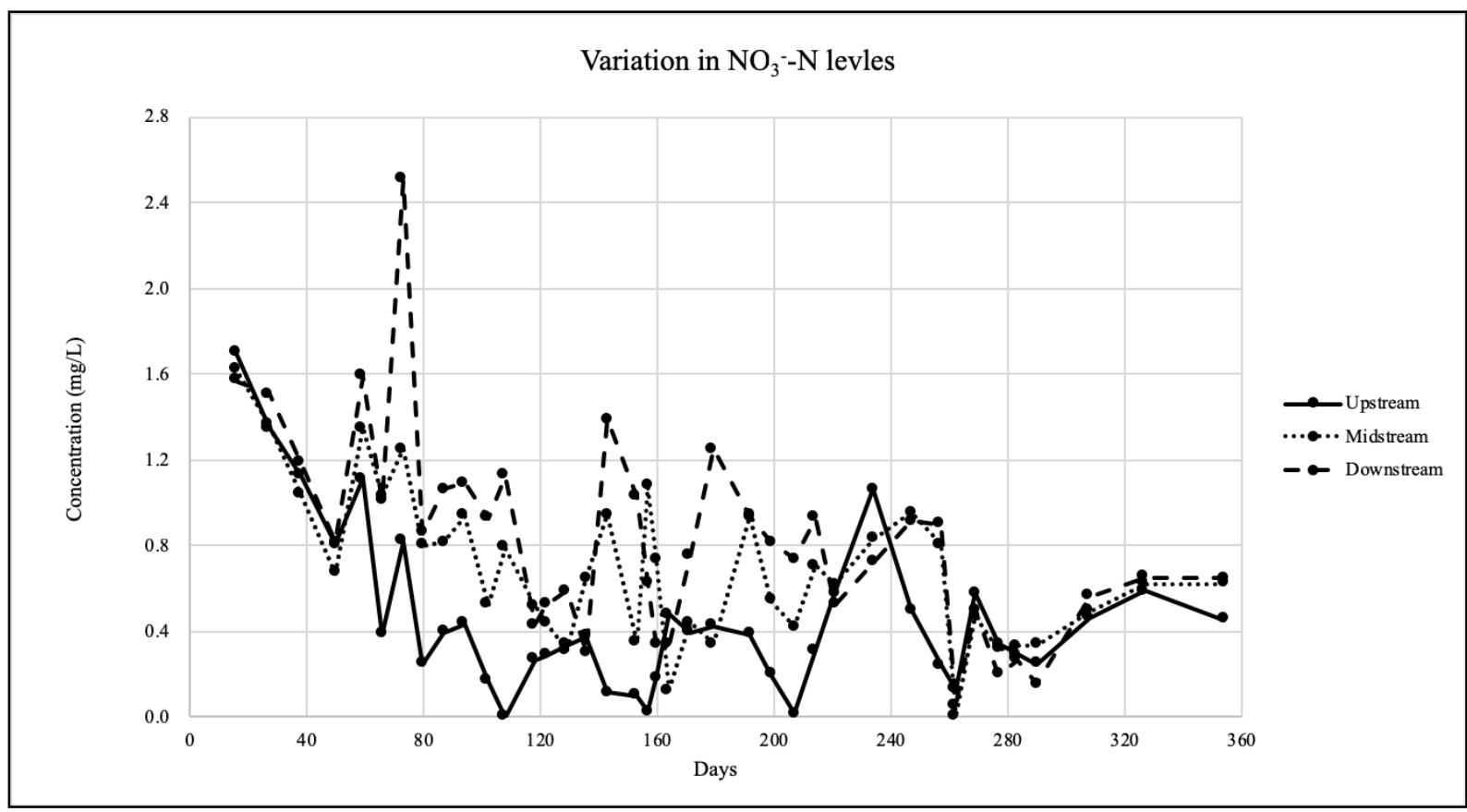

Figure 7. Variation in NO3--N levels in the upstream, midstream, and downstream reaches of the Xiangxi River

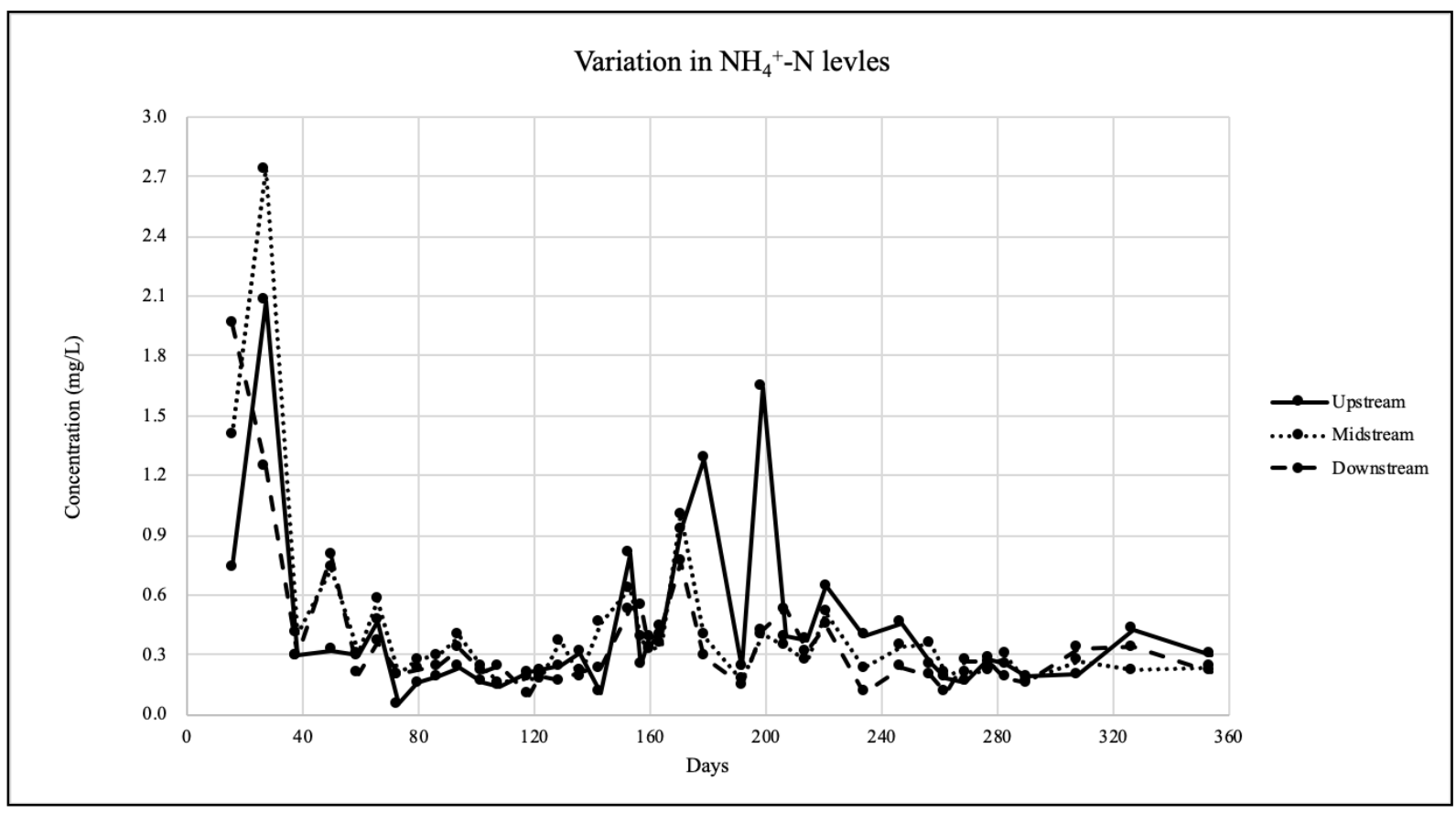

Figure 8. Variation in NH4+-N levels in the upstream, midstream, and downstream reaches of the Xiangxi River

\subsubsection{Ammonia}

Figure 8 shows the variation in the ammonia levels in the upstream, midstream, and downstream reaches of the Xiangxi River. The ammonia in the upstream section ranges from $0.05 \mathrm{mg} / \mathrm{L}$ to $2.08 \mathrm{mg} / \mathrm{L}$, in the midstream section it ranges from $0.16 \mathrm{mg} / \mathrm{L}$ to $2.74 \mathrm{mg} / \mathrm{L}$, and in the downstream section it ranges from $0.10 \mathrm{mg} / \mathrm{L}$ to $1.96 \mathrm{mg} / \mathrm{L}$ in downstream. The average concentrations of ammonia are $0.43 \mathrm{mg} / \mathrm{L}, 0.43 \mathrm{mg} / \mathrm{L}, 0.37 \mathrm{mg} / \mathrm{L}$ in the upstream, midstream, and downstream reaches, respectively. The variation in these concentration trends is gradually decreasing in all three reaches.

Looking at Figure 8, the trend in the ammonia data is different from those for the total nitrogen and nitrates. The concentration of ammonia is relatively low in general, probably due to nitrification. Microorganisms use carbon dioxide as a carbon source, oxidizing ammonia to form nitrate under aerobic conditions to obtain energy. The nitrate produced by this process is a nutrient for algae, promoting its growth and accelerating the eutrophication 
process.

In January, the concentration of ammonia reached its highest value for the year due to the backflow from the main stream of the Yangtze River to the Xiangxi River. The concentration is also quite high during June and July along the entire river, but with the highest levels of ammonia in the upstream reaches. This is likely because the water quality is most strongly affected in this area by agriculture and industrial wastewater. Also, as this is the rainy period for the Xiangxi River the Three Gorges Reservoir needs to discharge water, which leads to an increase of water fluidity and decreases pollutant accumulations, thus reducing the midstream and downstream pollutant concentration.

\subsubsection{Total Phosphorus}

Figure 9 shows the variation in the total phosphorus in the Xiangxi River. The total phosphorus variation in the upstream sections ranges from $0.06 \mathrm{mg} / \mathrm{L}$ to $0.46 \mathrm{mg} / \mathrm{L}$, in the midstream sections the range is from $0.02 \mathrm{mg} / \mathrm{L}$ to 0.39 $\mathrm{mg} / \mathrm{L}$, and downstream it ranges from $0.03 \mathrm{mg} / \mathrm{L}$ to 0.18 $\mathrm{mg} / \mathrm{L}$. The average concentrations of total phosphorus are $0.19 \mathrm{mg} / \mathrm{L}, 0.12 \mathrm{mg} / \mathrm{L}$, and $0.10 \mathrm{mg} / \mathrm{L}$ in the upstream, midstream, and downstream reaches, respectively. The overall trend in all three reaches shows a gradual decrease.

The concentration of phosphorus in the Xiangxi River is consistently greater than $0.09 \mathrm{mg} / \mathrm{L}$, which according to the standards listed in Table 4 means that the Xiangxi River rates as over-nourished over the whole year. Based on the eutrophication ranking corresponding to these concentrations in the evaluation criteria, the discharge of phosphorus-containing pollutants in the river is more significant than the levels of nitrogen-containing pollutants. There are abundant phosphorus and coal mine resources in the Xiangxi River Basin. [11] Phosphorite mining and processing, and phosphating plants are major industries in many villages and towns near the watershed.

The concentration of total phosphorus is highest in the upstream part of the river. Given the high emissions of phosphorus-containing pollutants from upstream sources, this is not surprising. In the lower reaches of the Xiangxi River, the variations in the phosphorus levels are less dramatic. In June and July, the concentration of total phosphorus is relatively high in both the upstream and downstream reaches. The Xiangxi River is in its wet season during this period, and the scour of rain water leads to an increase in the total phosphorus concentration in the river. As $18 \%$ of the total nitrogen and $15 \%$ of total phosphorus began to be intercepted in the reservoir after the impoundment of the Three Gorges Reservoir, the total phosphorus content in the main stream water body was less than that of the total nitrogen. As a consequence, the inverse flow of the main stream is unlikely to contribute substantially to the total phosphorus content of the Xiangxi River. Phosphorus is fairly heavy and thus tends to settle into the river sediment, which also reduces phosphorus levels.

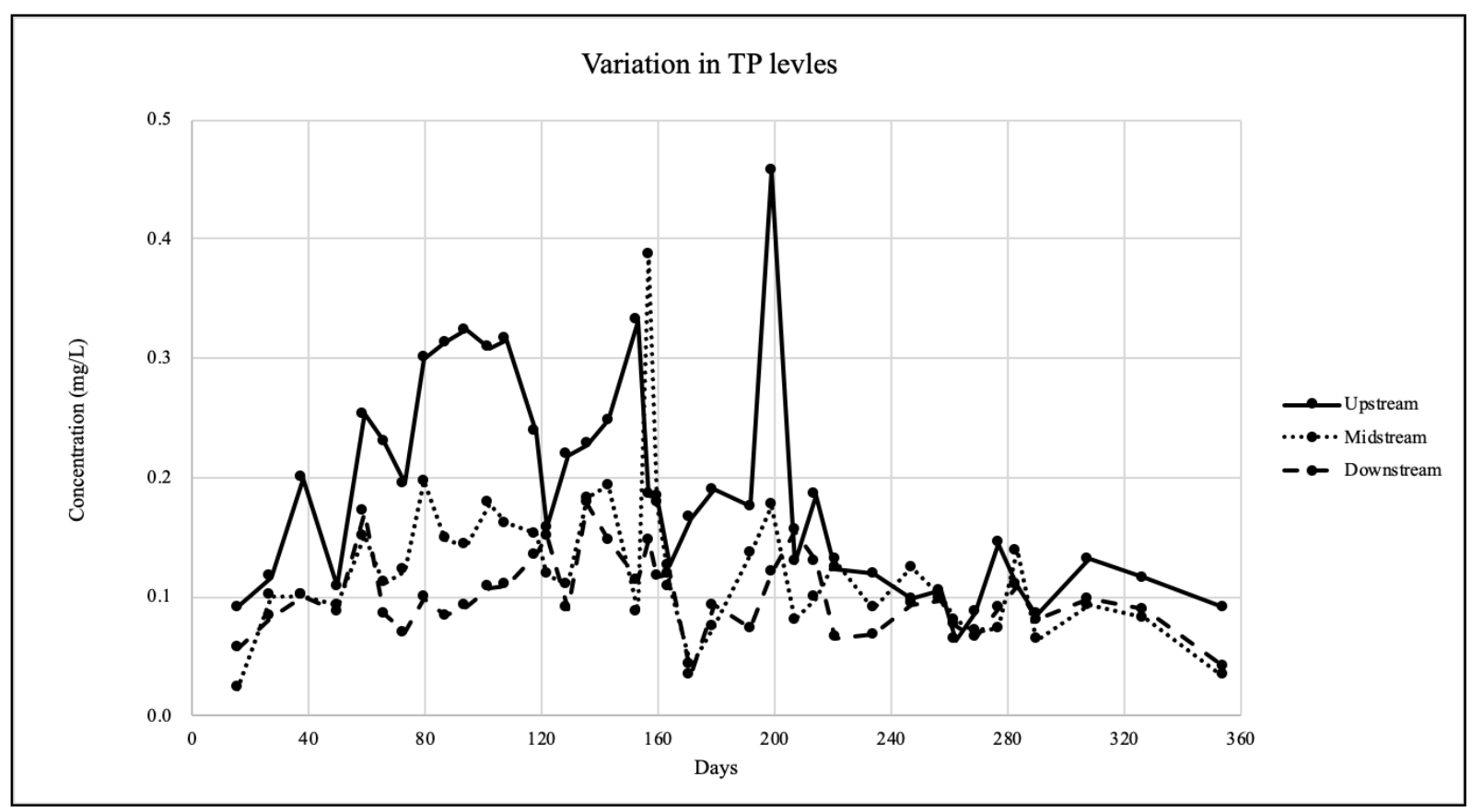

Figure 9. Variation in TP levels in the upstream, midstream, and downstream reaches of the Xiangxi River 


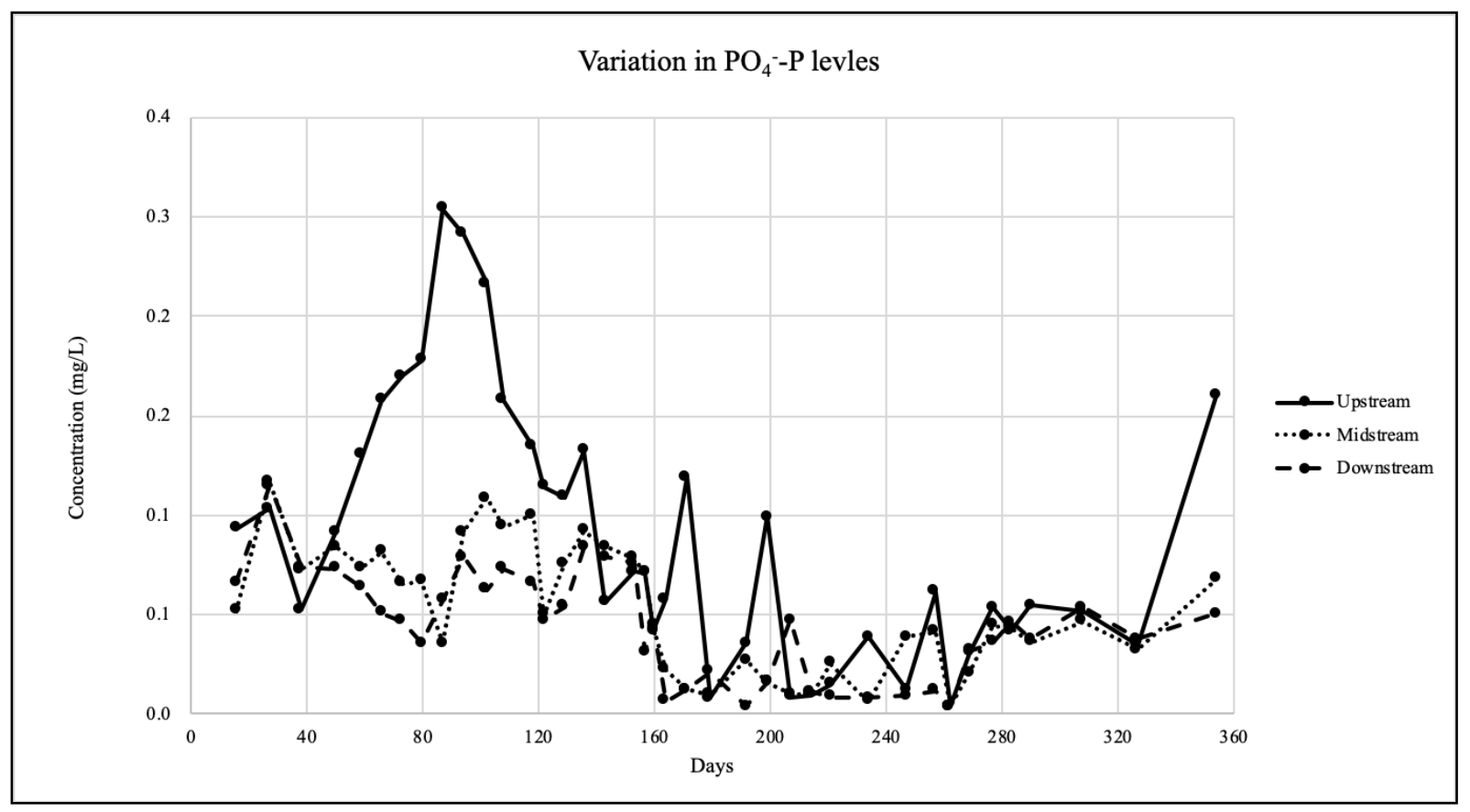

Figure 10. Variation on PO4--P levels in the upstream, midstream, and downstream reaches of the Xiangxi River

\subsubsection{Orthophosphate}

Figure 10 shows the variation in the orthophosphate levels in the upstream, midstream, and downstream reaches of the Xiangxi River. In the upstream reaches, the orthophosphate levels range from $0.00 \mathrm{mg} / \mathrm{L}$ to $0.30 \mathrm{mg} / \mathrm{L}$, in the midstream sections it ranges from $0.00 \mathrm{mg} / \mathrm{L}$ to 0.14 $\mathrm{mg} / \mathrm{L}$, and in the downstream sections it ranges from 0.00 $\mathrm{mg} / \mathrm{L}$ to $0.14 \mathrm{mg} / \mathrm{L}$. The average orthophosphate concentration is $0.11 \mathrm{mg} / \mathrm{L}, 0.06 \mathrm{mg} / \mathrm{L}$, and $0.05 \mathrm{mg} / \mathrm{L}$ in the upstream, midstream, and downstream reaches, respectively. The trends in the variation in the concentrations are gradually decreasing along the whole length of the river. This is not necessarily good news: orthophosphate is the only phosphorus-containing compound that algae can use directly, so when an algal bloom occurs the concentration of orthophosphate is decreasing.

Table 5. The criteria used to assess the degree of eutrophication

\begin{tabular}{|c|c|c|}
\hline Degree & Chl-a $(\mu \mathrm{g} / \mathrm{L})$ & Algae density $\left(10^{4}\right.$ cell $\left./ \mathrm{L}\right)$ \\
\hline Mild & $30-150$ & $1-10$ \\
\hline Moderate & $105-300$ & $10-20$ \\
\hline Severe & $>300$ & $>20$ \\
\hline
\end{tabular}

\subsubsection{Algal Density}

Zheng and others, [12,13] suggested standards for measuring algal blooms based on the content of the algal cells and different concentrations of chlorophyll a, utilizing as a reference standard the value measured for a specific lake and reservoir project, BBZB1-1999, and evaluation criteria for eutrophication in China, as shown in Table 5.

Figure 11 shows the variation in the algal density in the upstream, midstream, and downstream reaches of the Xiangxi River. The algae density in the upstream section ranged from $35000.00 \mathrm{NO} . / \mathrm{mL}$ to $90505834.28 \mathrm{NO} . / \mathrm{mL}$, in the midstream section it ranged from $65000 \mathrm{NO} . / \mathrm{mL}$ to $85197534.96 \mathrm{NO} . / \mathrm{mL}$, and in the downstream section it ranged from $3750 \mathrm{NO} . / \mathrm{mL}$ to $127307386.6 \mathrm{NO} . / \mathrm{mL}$. The average concentration of chlorophyll-a was 21018301.7 NO./mL, $21337234.41 \quad \mathrm{NO} . / \mathrm{mL}$, and 28548229.62 $\mathrm{NO} / \mathrm{mL}$ in the upstream, midstream, and downstream reaches, respectively. According to the standard criteria, the algal density is well over the $20 * 10^{4}$ cell/L level, corresponding to a severe algal bloom. Due to the accumulation of nutrients over the years, the trends in these concentrations are gradually increasing in all three reaches.

For this project, the species of algae measured included dinoflagellates, diatoms, green algae, cryptophytae, blue-green algae, xanthophytes, and euglenophytae. The number of chrysophyceae was very low and they were thus not included. As Figure 11 shows, the algal density is higher after April. 


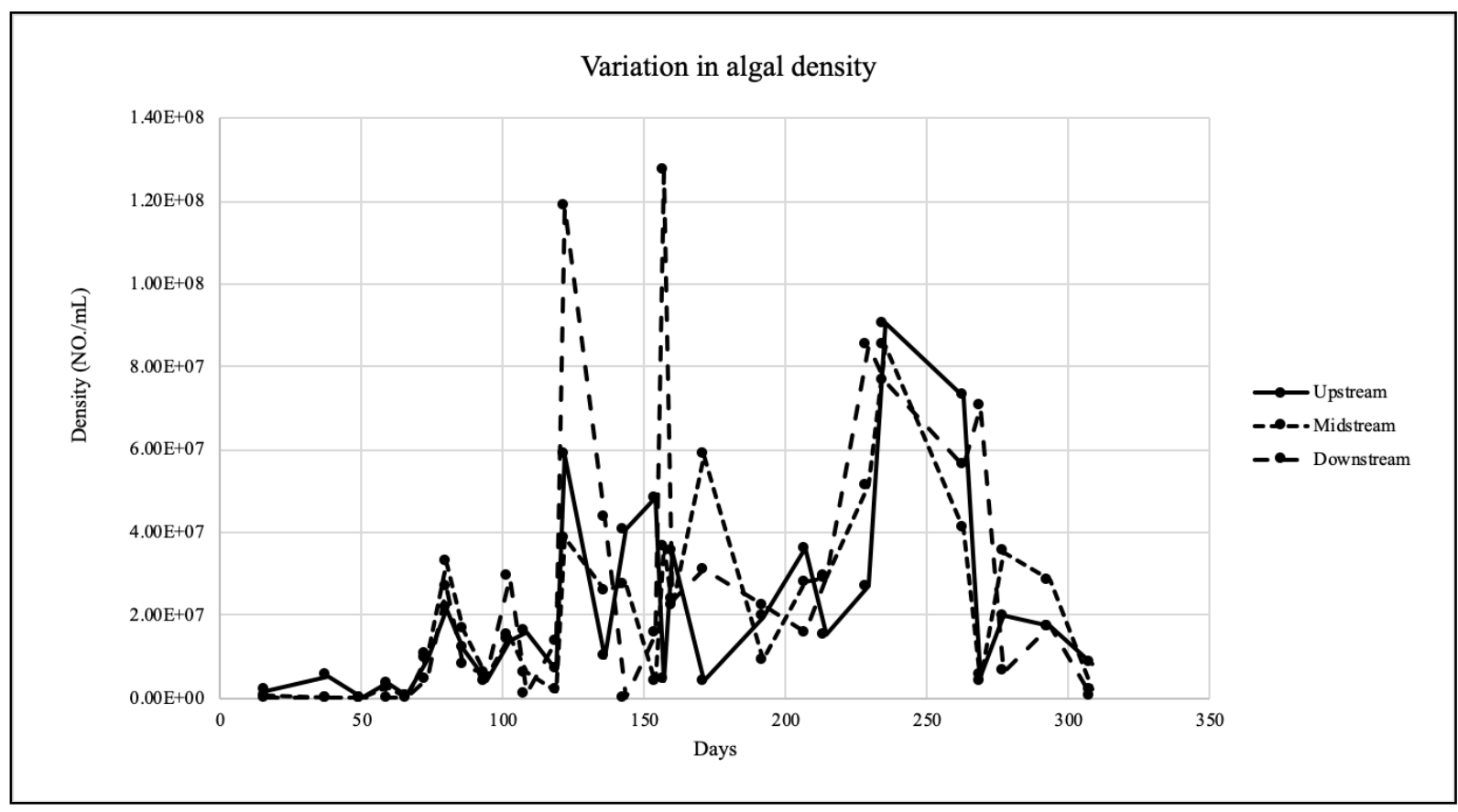

Figure 11. Variation in algal density in the upstream, midstream, and downstream reaches of the Xiangxi River

\subsubsection{Water Budget}

The result of the mass balance calculation for water (i.e. the water budget) is shown as Figure 12. Rainfall, river inflow, and river outflow are all known quantities, enabling the accumulation $\Delta \mathrm{s} / \Delta \mathrm{t}$ to be calculated. According to the calculation, the amount of water accumulated in the Xiangxi River was $1.108 \mathrm{E}+10 \mathrm{~m}^{3}$ over the period January to November 2010.

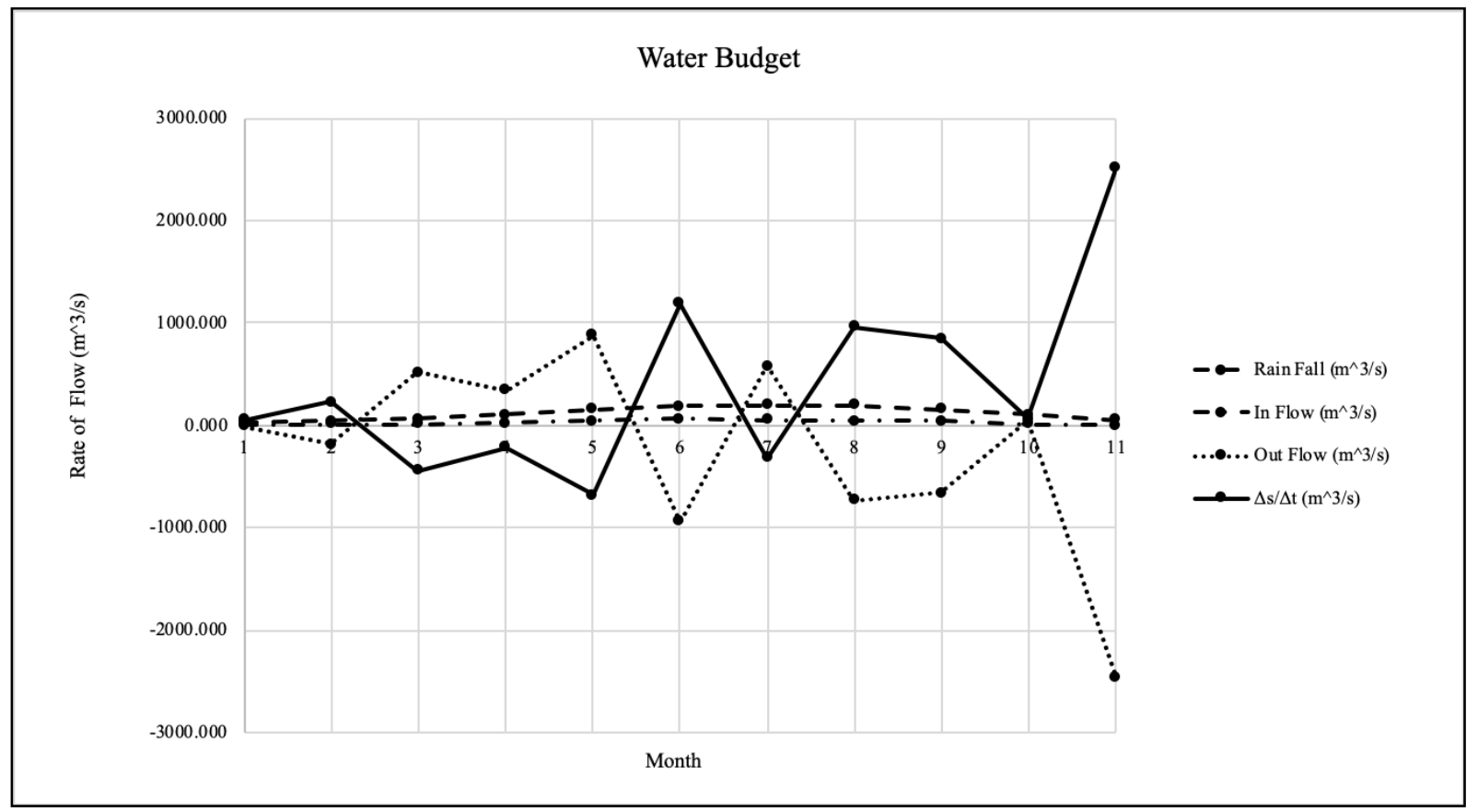

Figure 12. Water quantity variation in the Xiangxi River during the study period 
As Figure 12 shows, the rainfall and river inflow are very small compared to the river outflow, so the area in the cumulative graph is approximately equal to the area in the outflow graph, but a mirror image.

In general, the cross-sectional areas gradually increase from upstream to downstream. There is a backwater area in the lower reaches of Xiangxi River where the river channel has become silted up and the surface of the river becomes wider. Overall, for the period from January to November 2010 , the water level rose by $5.78 \mathrm{~m}$. This indicates that both the quantity of water accumulated and the rise in the water level are substantial.

\subsubsection{Mass Balance for Contaminants}

\subsubsection{Total Phosphorus}

Figure 13 shows the mass balance for total phosphorus in the upstream to midstream part of the Xiangxi River for ten months in 2010, from February to November.

Figure 13 shows that the accumulation of total phosphorus in the upper half of the river during this period was 16.053 tons. Of the phosphorus arriving in the river, from point sources $\left(\mathrm{CQ}_{\text {in-point }}\right)$ was 148.170 tons $(\sim 10 \%)$ and that from non-point sources $\left(\mathrm{CQ}_{\text {in-non point }}\right)$ was 1362.789 tons $(\sim 90 \%)$.

Figure 14 presents the results of the mass balance for total phosphorus for the lower half of the river, from midstream to downstream, in 2010, in the ten months from February to November.

Unfortunately, four of the non-point data readings were not available. If the value of non-point source pollution is negative, the likelihood of backflow occurring is $100 \%$, but even when the non-point source value is positive, as in March, the amount of backflow is small and can be ignored. Therefore, excluding backflow, the percentages of point source pollution and non-point pollution are $20 \%$ and $80 \%$, respectively, in the lower half of the river. The accumulation of total phosphorus in this section over the ten months study period was 14.803 tons.

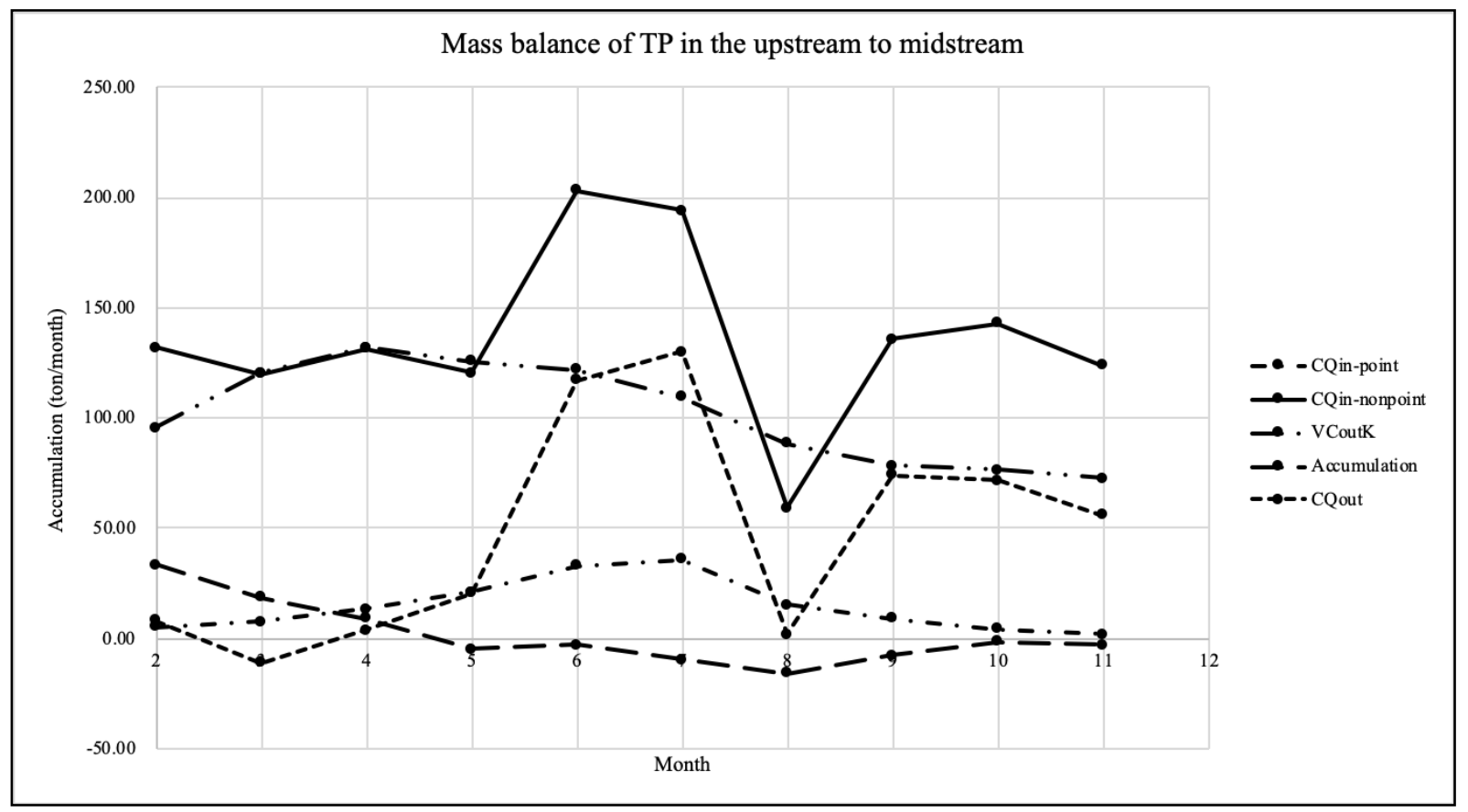

Figure 13. Mass balance of total phosphorus in the upstream to midstream reaches of the Xiangxi River (February to November 2010) 


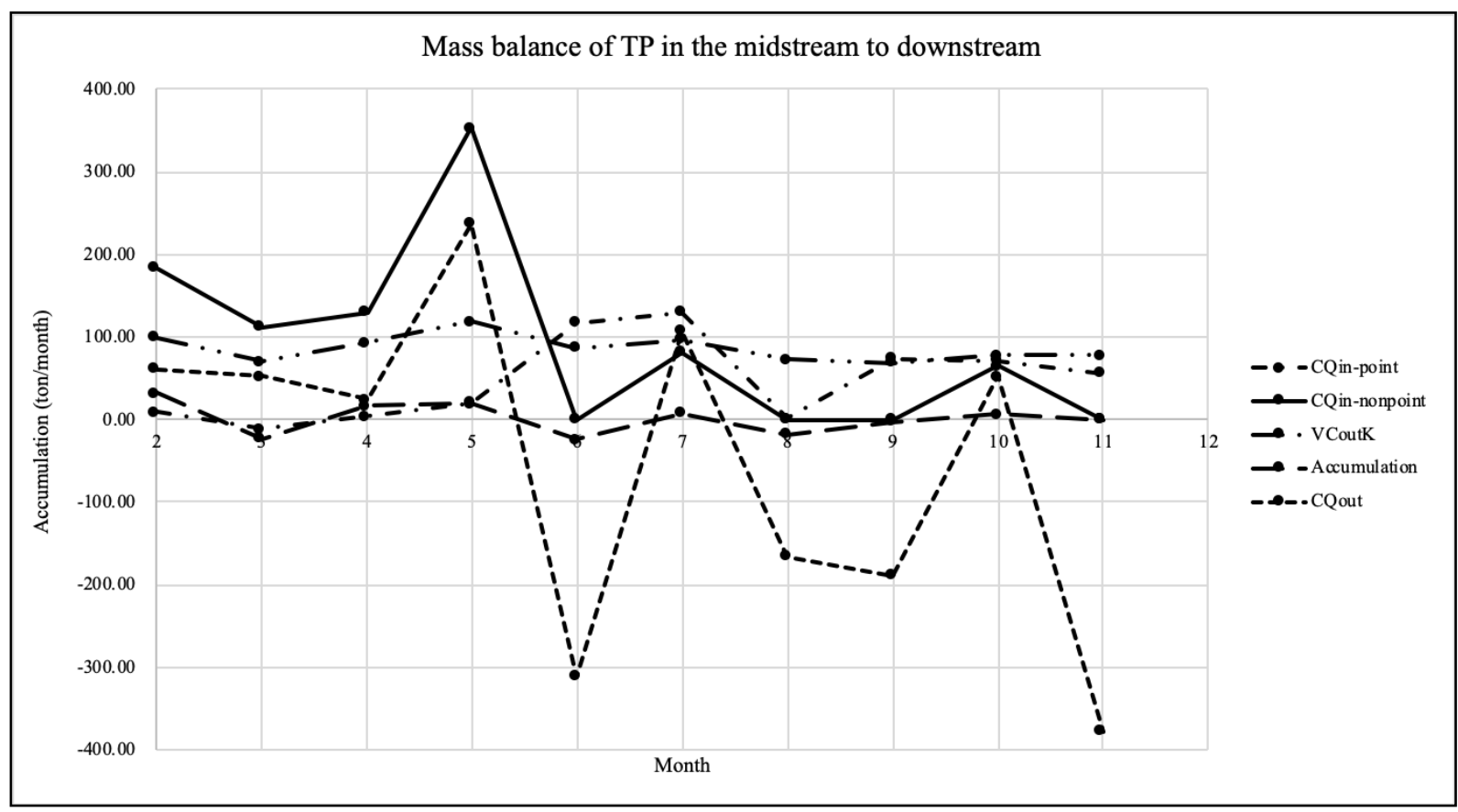

Figure 14. Mass balance of total phosphorus in the midstream to downstream reaches of the Xiangxi River (February to November 2010)

\subsubsection{Ammonia Nitrogen}

Figure 15 shows the mass balance results for ammonia nitrogen in the upper half, from upstream to midstream, of the Xiangxi River, from March to November 2010.

As the data presented in Figure 15 show, the accumulation of ammonia nitrogen during the nine months study period was -148.091 tons for 9 months. According to the previous analysis, the algal density was very high during this period, so a lot of ammonia nitrogen was consumed by the algae. The percentages of point source pollution and non-point pollution in this section of the river were $12 \%$ and $88 \%$, respectively.

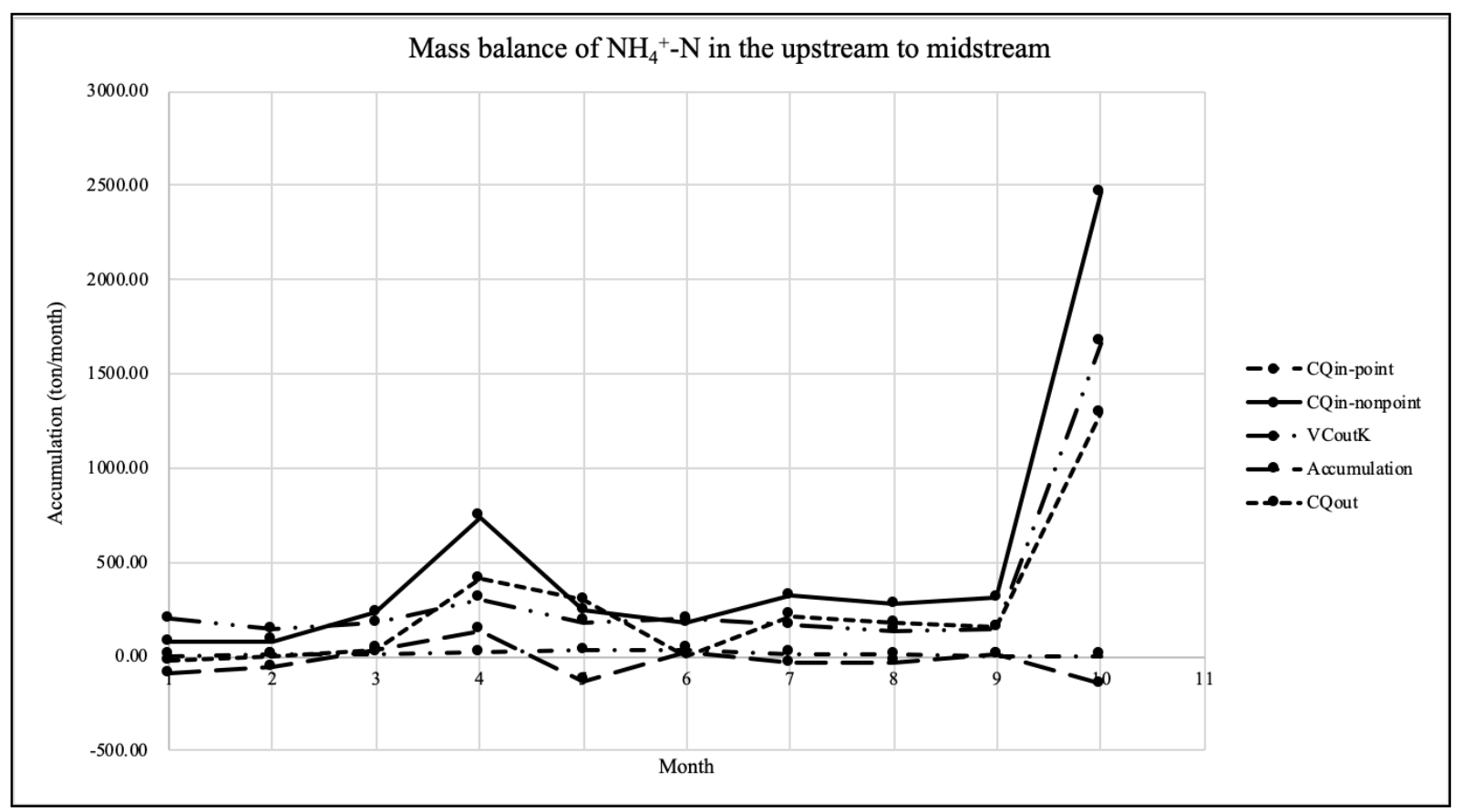

Figure 15. Mass balance of ammonia nitrogen in the upstream to midstream reaches of the Xiangxi River (March to November 2010) 


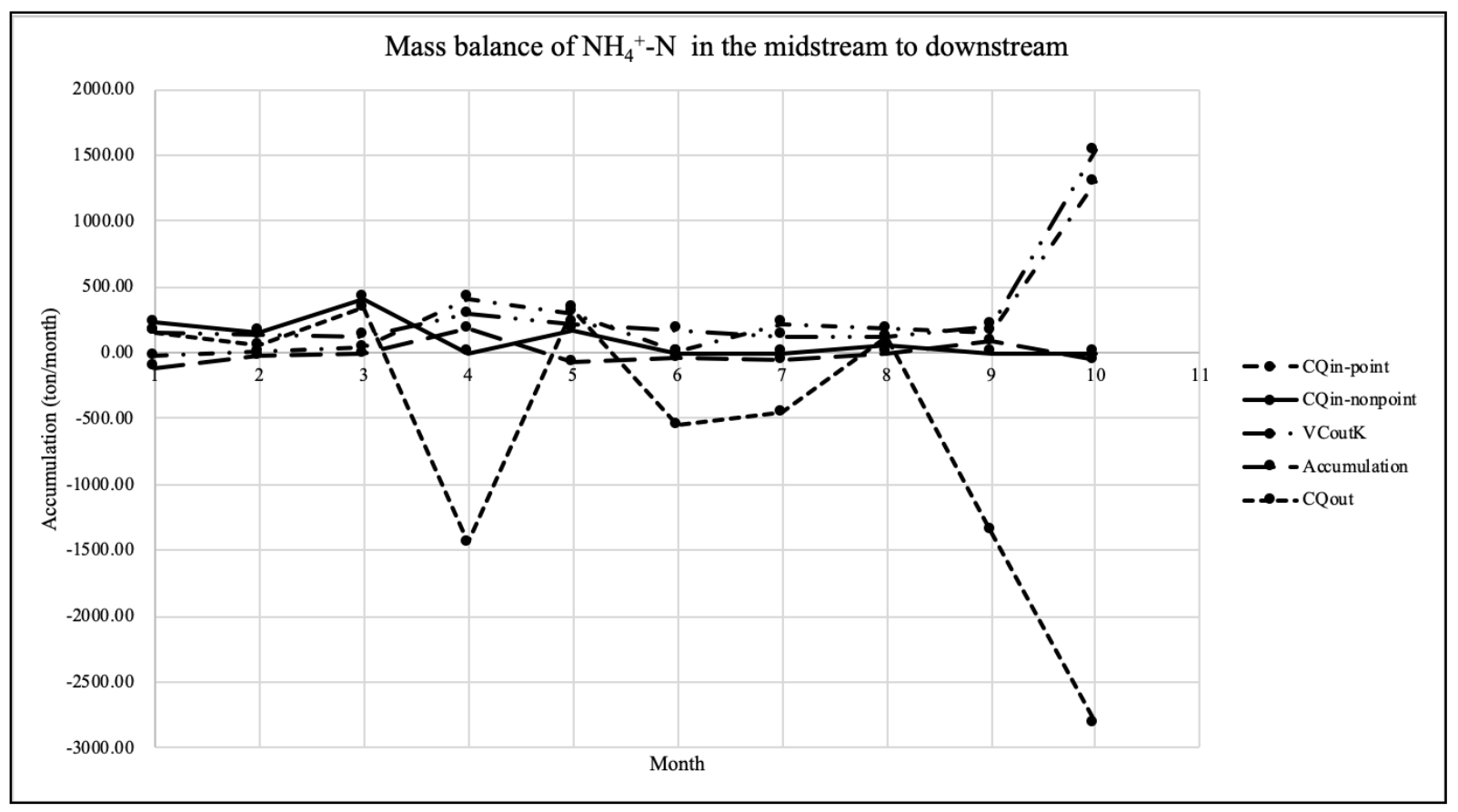

Figure 16. Mass balance of ammonia nitrogen in the midstream to downstream reaches of the Xiangxi River (March to November 2010)

Figure 16 shows the mass balance results for ammonia nitrogen in the lower half, from midstream to downstream, of the Xiangxi River, from March to November.

As the data in Figure 16 shows, the accumulation of ammonia nitrogen was -61.814 tons over the nine months. As noted earlier, the variation trend in algae concentrations in the upstream, midstream, and downstream reaches of the Xiangxi River are all gradually increasing. In the lower half of the river, the percentages of point source pollution and non-point pollution were $33 \%$ and $67 \%$ in the second part, respectively. Once again some of the data for ammonia nitrogen was not available. However, when the non-point source pollution is negative, $C Q_{\text {out }}$ is also negative, as it is for the total phosphorus, and if the non-point source pollution is negative, the likelihood of backflow occurring is $100 \%$.

\section{Conclusions}

This research found that in the Xiangxi River Bay area, the concentration of total nitrogen, nitrate, and algal density increased from upstream to downstream during the study period. The variation of ammonia, total phosphorus, orthophosphate and chlorophyll-a exhibited the opposite trend. During the eutrophication process, total nitrogen is the limiting factor. Changes in the algal density are accompanied by changes in the hydrodynamic characteristics. The river's flow velocity in the bay area is very slow, and backflow events occur frequently.

The amount of water accumulating in the Xiangxi River was $1.108 \mathrm{E}+10 \mathrm{~m}^{3}$ during the period January to November 2010. Rainfall and river inflow are very small compared to river outflow and backflow contributes substantially to the water accumulation in the Xiangxi River. From January to November 2010, the water level rose by $5.78 \mathrm{~m}$. The river's cross-sectional area gradually increased from upstream to downstream. Most of the phosphorus and ammonia in the river came from non-point source pollution, so controlling the discharge of agricultural wastewater is important for improving the water quality. Due to the backflow, there were some values for non-point source pollution that were not available; if the value of non-point source pollution is negative, the likelihood of backflow is $100 \%$.

The findings of this research provide useful information regarding the degree of eutrophication in the Xiangxi River. This will be especially helpful for environmental managers seeking new ways to control water pollution.

\section{Acknowledgements}

We would like to thank China's Three Gorges University for providing the data used in this analysis.

\section{REFERENCES}

[1] Varol, M.; Gökot, B.; Bekleyen, A.; Şen, B. Water Quality Assessment and Apportionment of Pollution Sources of Tigris River (Turkey) Using Multivariate Statistical Techniques: A Case Study. River Research and Applications 2012, 28(9), 1428-1438.

[2] Liu, R.; Zhang, P.; Wang, X.; Chen, Y.; Shen, Z. Assessment of Effects of Best Management Practices On Agricultural 
Non-point Source Pollution in Xiangxi River Watershed." Agricultural Water Management 2013, 117, 9-18.

[3] Liu, L.; Liu, D.; Johnson, D. M.; Yi, Z.; Huang, Y. Effects of Vertical Mixing On Phytoplankton Blooms in Xiangxi Bay of Three Gorges Reservoir: Implications For Management Water Research 2012, 46(7), 2121-2130.

[4] Liu, D. F.; Huang, Y. L.; Ji. D. B. Algae Bloom and Ecological Regulation of the Tributaries of the Three Gorges Reservoir. Beijing: China Water Conservancy and Hydropower Publishing House, 2013.

[5] Huang, Y. L.; Huang, G. H.; Liu, D. F.; Zhu, H.; Sun, W. Simulation-based Inexact Chance-constrained Nonlinear Programming for Eutrophication Management in the Xiangxi Bay of Three Gorges Reservoir. Journal of Environmental Management 2012, 108, 54-65.

[6] Baker, D. B.; Confesor, R.; Ewing, D. E.; Johnson, L. T.; Kramer, J. W.; Merryfield, B. J. Phosphorus Loading to Lake Erie From the Maumee, Sandusky and Cuyahoga Rivers: The Importance of Bioavailability. Journal of Great Lakes Research 2014, 40(3), 502-517.

[7] Jordan, P.; Melland, A. R.; Mellander, P. E.; Shortle, G.; Wall, D. The Seasonality of Phosphorus Transfers From Land to Water: Implications For Trophic Impacts and Policy Evaluation. Science of the Total Environment 2012, 434, 101-109.

[8] Chislock, M. F.; Doster, E.; Zitomer, R. A.; Wilson, A. E. (2013) Eutrophication: Causes, Consequences, and Controls in Aquatic Ecosystems. Nature Education Knowledge 2013, 4(4):10

[9] Ji, Z. G. Hydrodynamics and Water Quality - Modeling Rivers, Lakes, and Estuaries. 1st ed. Hoboken, New Jersey: John Wiley \& Sons, Inc.; 2007. 676 p.

[10] Lehtiniemi, M.; Engström-Öst; Viitasalo, M. Turbidity decreases anti-predator behaviour in pike larvae, Esox Lucius. Environmental Biology of Fishes 2005, 73, 1-8 (2005).

[11] Ye, L. The Occurrence Rule and Countermeasure Study on Algae Blooms of Xiangxi River in the Three Georges Reservoir Area. Ph.D. dissertation, Hohai University, Nanjing, China, 2006 [in Chinese].

[12] Zhang, C. Distributed Non-point Sources Pollution Modeling and Its Application in Xiangxi Watershed. Ph.D. Dissertation, Tsinghua University, Beijing, China, 2008 [in Chinese].

[13] Zhang, M. Study on the Succession and Clustering of Algae and Pollution Status of Algal bloom in Representative Water Systems along the Three-Gorges Valley. Ph.D. Dissertation, Chongqing University, Chongqing, China, 2008 [in Chinese].

[14] Sheng, J. P. Seasonal Variation of Phytoplankton Community in Xiaoiang Backwater Area of the Three Gorges Reservoir. Ph.D. Dissertation, Chongqing University, Chongqing, China, 2010 [in Chinese].

[15] Huang, Z. L.; Li. Y. L.; Chen. Y. C. Water Quality Prediction and Environmental Capacity Calculation of the Three Gorges Reservoir. Beijing: China Water Conservancy and Hydropower Publishing House, 2006.
[16] Yoo, J.-C.; Han, T. H. Fast Normalized Cross-correlation." Circuits, Systems and Signal Processing 2009, 28(6), 819.

[17] Ran, X. B.; Yao, Q. Z.; Gong, Y. Calculation of Nutrient Budget of Three Gorges Reservoir Before and After Impoundment. Journal of Water Ecology 2009, 2(2), 1-8.

[18] Abell, J. M.; Özkundakci, D.; Hamilton, D. P. Nitrogen and Phosphorus Limitation of Phytoplankton Growth in New Zealand Lakes: Implications for Eutrophication Control. Ecosystems 2010, 13(7), 966-977.

[19] Bierman, V. J.; Hinz, S. C.; Zhu, D.-W.; Wiseman, W. J.; Rabalais, N. N.; Turner, R. E. A Preliminary Mass Balance Model of Primary Productivity and Dissolved Oxygen in the Mississippi River Plume/Inner Gulf Shelf Region. Estuaries 1994, 17(4), 886-899.

[20] Davis, M.; Masten, S. Principle of Environmental Engineering and Science, 3rd ed, 2014, McGraw-Hill.

[21] Zhang, Y.; Liu, D. F.; Ji, D. B. Resupply of Nutrient in Xiangxi River Reservoir Bay by Heavy Flow of Reverse Irrigation in Main Flow. Environmental Sciences 2012, 33(8), 2621-2627.

[22] Wang, H. Y.; Cheng, S. G.; Huang, L. Study on the Genetic Conditions of Algae Bloom in the Three Gorges Reservoir. People's Yangtze River 2007, 38(2). 